\title{
Increasing Study Abroad Participation: The Faculty Makes the Difference
}

\author{
Ev a Pa u s \\ Mount Holyoke College \\ Michael Robinson \\ Mount Holyoke College
}

For their own future and that of the nation, it is essential that college graduates today become globally competent. Lincoln Commission (2005)

\section{Introd uction*}

Study abroad is a key element in students' education for careers and citizenship in a globalizing world. It provides unique opportunities for students to learn about and appreciate cultures and perspectives different from their own, to confront and explore their own assumptions, to achieve greater proficiency in another language and to grapple with the challenge of living in an unfamiliar context.

At most institutions of higher education in the U.S., students' participation in study abroad falls dramatically short of what would be desirable given the broadly shared aspiration to educate globally competent students. ${ }^{1}$ In 2004-05, only 1.2 percent of undergraduates at U.S. colleges and universities were studying abroad. Yet, awareness of the importance of expanding study abroad is reflected in recent public opinion polls and policy initiatives in the United States and elsewhere. One study suggests that more than 75 percent of parents with children in college consider study abroad an important part of their children's college education (NAFSA 2006). In 2005, the Lincoln Commission called for a quintupling of the annual number of U.S. students studying abroad, to one million by 2016-17 (Commission 2005).

To close the gap between where we are and where the Lincoln Commission wants us to go and beyond, we need a better understanding of the factors that motivate some students to study abroad and deter others from doing so.

*The authors thank the Teagle Foundation for supporting the production of a White Paper on expanding learning abroad (Paus 2007). It forms the basis for some of the discussion in this article and is available at http://www.teaglefoundation.org/learning/pdf/mtholyoke_whitepaper.pdf. 
The annual Open Doors report of the Institute for International Education provides detailed national statistics on undergraduates studying abroad. The report shows an under-representation of science majors, men, and students of color in the study abroad population. The existing literature also identifies key impediments to study abroad, most importantly cost considerations and apprehension about the unfamiliar. In order to devise the most effective policies at the institutional level to expand education abroad participation, educational decision-makers need to know which of the factors that play an important role in study abroad generally are the most important ones in students' study abroad decisions at their particular institution. Good policies are based on institution-specific analysis.

In this paper, we propose one model for such an analysis which we then apply to the study of our home institution, Mount Holyoke College. The paper advances our understanding of the determinants of study abroad in two important ways. First, it shows that going beyond descriptive statistics and simple correlations and using multivariate analysis allows one to isolate the factors that are statistically most important in the study abroad context of a particular institution. Such results, in turn, make it possible to assess the effectiveness of some of the institution's existing policies for expanding study abroad and to identify new areas for policy intervention.

Second, our analysis of the Mount Holyoke College case identifies parent and faculty encouragement as key determinants of a student's study abroad decision. We stress the role of the faculty in increasing study abroad participation because the statistical coefficient on their encouragement is larger, because it is more feasible to involve faculty in a student's study abroad decision than to involve parents, and because faculty encouragement of study abroad may well be the key to enticing significantly more students to study abroad, especially from groups which have been underrepresented in study abroad.

\section{A Model for Institutional Study Abroad Analysis: Who Studies Abroad?}

This study groups the determinants of study abroad into four categories: student background characteristics, student comfort with risk and cultural difference, college-related factors, and encouragement effects. While some of the variables in the four sets of categories are likely to be interrelated, they have been separated into different categories for the sake of analytical clarity and more targeted policies aimed at expanding study abroad participation.

'Student background' refers to student characteristics which — based on the literature - capture potential financial and cultural barriers to study 
abroad, namely race/ethnicity and family income. Students of color are generally underrepresented in study abroad, as evidenced in the national data published by the International Institute of Education and discussed in several studies (Dessoff 2006, Jackson 2005, LeMay Burr 2005). There are a number of reasons why minority students may be less inclined to study abroad. Van der Meid (2003) discusses studies which stress fear of discrimination abroad as one important factor. He argues that "a common thread in most factors [... is the minority students' lack of reassurance about their abilities in a study abroad program" (77).

While there are no national data on family income of students studying abroad compared to those who do not, students have consistently ranked concern about financing among the main reasons why they do not study abroad (Thompson 2007, Dessoff 2006, Chieffo 2000). As a result, an institution's financial aid policy is critical in overcoming the financial concerns of potential study abroad students. Pappano (2007) succinctly summarizes that "for most students, financial aid is the biggest factor in affording study abroad."

Numerous studies have stressed the importance of students' openness towards new experiences and cultures as an important determinant of studying abroad. In an analysis of the factors influencing Asian-Americans' decision to study abroad, for example, Van der Meid $(2003,104)$ found that "study abroad students are more adventurous and motivated, while Non-Study Abroad students are more cautious." Goldstein and Kim (2006) found no statistical difference though with respect to tolerance of ambiguity and travel experience between students who studied abroad and those who did not. In their study, the statistically significant factors that characterized the study abroad students were more positive expectations of study abroad, less ethno-centrism, and a less discriminating attitude.

A third set of variables influencing a student's study abroad decision captures students' attributes as they unfold in their college years: major, academic performance, and extra-curricular activities. Science majors' perceptions of tight course sequencing and concerns about credit transfer often mitigate against study abroad participation, while many foreign language majors consider study abroad essential for the major. Students with a lower grade point average (GPA) may be less confident about their ability to succeed abroad. They may also feel pressure to raise their GPA, which cannot happen through study abroad if their institution transfers in only credits but not grades, which is frequently the case. A student's extracurricular activities may also play an important role in the study abroad decision. Athletes, in particular, may be less inclined to study abroad if it means missing a season. 
The final set of variables focuses on who encourages students to study abroad. Encouragement from family, friends, and faculty members may be a significant factor in allaying students' anxieties about life in a different country and culture or apprehension about how study abroad might fit in with major and extra-curricular activities. Chieffo (2000) found that more students reported that parents and friends, rather than faculty, had considerable influence on their decision to participate in study abroad. With respect to faculty's role in providing students with information about study abroad programs, Chieffo $(2000,66)$ found large differences between faculty members in the languages versus those in other departments in the amount of study abroad information they provide to students. Three quarters of students in foreign language classes reported to have received 'much' or 'some' information about study abroad program from their faculty members, compared to 20 percent of students in non-language classes. One reason why faculty are found to have little influence in Chieffo's study may be because her results are based on student participation in short-term study abroad programs during January, which faculty may consider less academically serious than semester or year-long programs abroad. Nearly all the students in Chieffo's study (94.6 percent) indicated that the 'opportunity for fun and travel' had a great influence on their decision to participate in the short-term program.

\section{Estimation Technique, Data Sources and Variables}

In the equation below we summarize our proposed model of the determinants of the probability of a student studying abroad:

$$
P(S A)=f(S B, R A, C R F, E E),
$$

where 'P (SA)' is the probability that a student will study abroad, 'SB' refers to student background variables, 'RA' to student risk aversion, 'CRF' to college-related factors, and 'EE' to encouragement effects.

We estimated the equation for one particular institution of higher education, Mount Holyoke College. We chose Mount Holyoke College for two reasons. First, as it is our home institution we were in a position to access or generate the necessary institution-specific data. Second, in addition to being of academic interest, the analysis has directly relevant policy implications, since Mount Holyoke has identified education for global citizenship as a top priority for the college, and expansion of learning abroad participation is one important step towards the realization of that goal. Further, a grant from the Teagle Foundation allowed Mount Holyoke to bring together a working group of all 
constituencies of the college to develop a strategy for a leap forward in learning abroad (see Paus, 2007).

To understand why some students study abroad and others do not, we used a multivariate analysis to identify those individual variables which are statistically significant when we control for the influence of the other independent variables. Since the dependent variable in the equation is binary, we adopted a probit model for the estimation.

We use two different data sets for our analysis: comprehensive official data on all Mount Holyoke students who entered the college during the period 2001-2004 and senior survey data for the class of 2007. For the comprehensive data, we merged admissions data for 2,335 students with data on their study abroad participation and majors. The resulting data set provides information on student background, risk-aversion, and college-related factors. We use 'family income/family contribution,' 'race,' and 'first generation' as variables for 'student background,' and 'major,' 'GPA,' and 'athletic participation' for 'college-related factors.' Since we have no direct measures of a student's risk aversion, we used two proxies: a student's geographic area of origin and whether she applied early decision or not. Our assumption is that students whose home is not far from Mount Holyoke College or who are applying early decision may be more risk averse than students whose home is further away or who did not apply early decision. The variables are, of course, imperfect proxies since they may also capture other student attributes that are unrelated to risk aversion.

Since the comprehensive data includes no information related to encouragement for study abroad, we generated the requisite data by adding several questions to the standard senior survey administered to the class of 2007. We asked students to indicate, among other things, the extent to which friends, family, and faculty members had played a role in their decision to study abroad or not.

In summary, for the probit analysis of the relationship in the equation, we use the following variables for the four sets of factors influencing a student's study abroad decision:

SB: race, family income/family contribution, first generation

RA: geographic origin, early decision

CRF: major, athlete, GPA

EE: friends' influence, parents' influence, faculty influence.

Table 1 below presents the estimates for two probit models; one based on senior survey data and the other on comprehensive data. The two probit models include student background variables and college-related variables. With only one exception (the income variable), coefficients of the same variables are consistently 
either statistically significant or not across the two models. In addition to student background and college-related factors, the senior survey-based estimate also includes the encouragement variables, while the comprehensive-based

Table 1. Determinants of Study Abroad Decisions: (Dependent variable 'Study Abroad' = ' 1 ' for study abroad and '0' otherwise)

\begin{tabular}{|c|c|c|c|c|}
\hline & \multicolumn{2}{|c|}{$\begin{array}{c}\text { Senior Survey-based } \\
\text { Probit } \\
\end{array}$} & \multicolumn{2}{|c|}{$\begin{array}{c}\text { Comprehensive data- } \\
\text { based Probit }\end{array}$} \\
\hline & Coeff & $\begin{array}{l}\text { Marg. } \\
\text { Effect }\end{array}$ & Coeff & $\begin{array}{l}\text { Marg. } \\
\text { Effect }\end{array}$ \\
\hline Intercept & $-2.30(-2.77)$ & & $-2.98(-7.79)$ & \\
\hline \multicolumn{5}{|l|}{ Background variables } \\
\hline $\begin{array}{l}\text { Income/Family } \\
\text { Contribution }\end{array}$ & $0.05(0.63)$ & $2.3 \%$ & $0.01(2.43)$ & $0.2 \%$ \\
\hline First generation & $0.03(0.13)$ & $1.3 \%$ & & \\
\hline $\begin{array}{l}\text { African } \\
\text { American/Hispanic }\end{array}$ & $-0.48(-1.41)$ & $-16.0 \%$ & $-0.01(-0.07)$ & $-0.3 \%$ \\
\hline Asian & $0.22(0.86)$ & $8.4 \%$ & $-0.01(-0.06)$ & $-0.3 \%$ \\
\hline International & $0.10(0.39)$ & $5.0 \%$ & $-0.17(-1.06)$ & $-6.1 \%$ \\
\hline \multicolumn{5}{|l|}{ Risk aversion proxies } \\
\hline Early Decision & $0.00(0.02)$ & $0.2 \%$ & $-0.11(-1.53)$ & $-4.0 \%$ \\
\hline East South Central & & & $-0.39(-1.00)$ & $-13.2 \%$ \\
\hline West South Central & & & $-0.10(-0.47)$ & $-3.8 \%$ \\
\hline East North Central & & & $0.07(0.49)$ & $2.7 \%$ \\
\hline West North Central & & & $0.33(1.74)$ & $13.0 \%$ \\
\hline Mountain & & & $0.26(1.21)$ & $10.2 \%$ \\
\hline Pacific & & & $0.24(2.31)$ & $9.5 \%$ \\
\hline Non-US & & & $0.38(2.44)$ & $14.7 \%$ \\
\hline \multicolumn{5}{|l|}{$\begin{array}{l}\text { College-related } \\
\text { variables }\end{array}$} \\
\hline Languages & $1.48(2.89)$ & $50.9 \%$ & $0.73(6.16)$ & $28.4 \%$ \\
\hline Science & $-0.45(-1.69)$ & $-14.9 \%$ & $-0.77 v$ & $-23.1 \%$ \\
\hline Social science & $-0.17(-0.72)$ & $-6.2 \%$ & $0.02(0.23)$ & $0.9 \%$ \\
\hline Humanities & $-0.40(-1.66)$ & $-13.7 \%$ & $-0.18(-1.74)$ & $-6.4 \%$ \\
\hline College GPA & $0.48(2.16)$ & $18.9 \%$ & $0.80(7.80)$ & $31.2 \%$ \\
\hline Athlete & $0.02(0.12)$ & $0.8 \%$ & $0.05(-6.72)$ & $2.0 \%$ \\
\hline \multicolumn{5}{|l|}{$\begin{array}{l}\text { Encouragement } \\
\text { variables }\end{array}$} \\
\hline Faculty encouragement & $0.82(3.99)$ & $31.7 \%$ & & \\
\hline Parental encouragement & $0.55(2.74)$ & $21.7 \%$ & & \\
\hline Friend encouragement & $0.31(1.49)$ & $12.0 \%$ & & \\
\hline $\mathrm{N}$ & 329 & & 1744 & \\
\hline Log-Likelihood & -166.9 & & -1067.2 & \\
\hline
\end{tabular}

bold: significant at the $5 \%$ level, italic: significant at the $10 \%$ level; T-statistics in brackets 
estimate includes geographic origin as a proxy for risk aversion. In Table 1 we report both the coefficients and the marginal effect on the probability of studying abroad for a unit change in each variable evaluated at the mean probability of study abroad of the sample.

\section{Discussion of Results Student Background}

The multivariate analysis shows that student background variables do not play a very important role in the likelihood of a Mount Holyoke student to study abroad. 'Race' and 'first generation' are not statistically significant. And while 'family income' is significant, its effect is relatively small.

At Mount Holyoke College, race is a less important factor in study abroad participation than suggested by the national data. In the comprehensive data, the study abroad participation rate for Caucasian domestic students was 34.9 percent (see Table 2). Asian-American students had the same rate as Caucasian students, Hispanic students had a higher rate, and African-American students had a slightly lower rate. The significantly lower rate for Native Americans is based on a very small number of observations. In the probit analysis we grouped African-American and Hispanic students together because of their relatively small numbers in the senior survey data.

Table 2. Study Abroad Participation Rates by Race, Citizenship, and Family Contribution

\begin{tabular}{|l|l|l|l|}
\hline Race/Citizenship & Percent & Family Contribution & Percent \\
\hline White & $34.9 \%$ & 10,000 or less & $35.1 \%$ \\
\hline African-American & $30.1 \%$ & 10,001 to 20,000 & $34.8 \%$ \\
\hline Hispanic & $36.7 \%$ & 20,001 to 30,000 & $33.4 \%$ \\
\hline Asian-American & $34.2 \%$ & 30,001 to No need & $31.1 \%$ \\
\hline Native American & $27.3 \%$ & No need & $39.6 \%$ \\
\hline International & $42.8 \%$ & & \\
\hline International living in US & $31.9 \%$ & & \\
\hline International living Abroad & $44.7 \%$ & & \\
\hline US Resident living Abroad & $50.7 \%$ & & \\
\hline Mean & $36.0 \%$ & & \\
\hline
\end{tabular}

International students constitute a relatively high percentage of the student population at Mount Holyoke College, 13.5 percent of the students in the comprehensive data. Their participation in study abroad is the highest of 
all groups. But the results show that an international student is no more likely to study abroad than a domestic student once we control for other factors.

Based on our analysis we reject the hypothesis that first generation college students are less likely to study abroad than students whose parents had gone to college. Since the senior survey-based model also controls for parental encouragement we expect that parental encouragement is more important than simply parents' education.

While cultural barriers to study abroad are not statistically significant at MHC, financial barriers are. Family contribution is statistically significant in the second model, once we control for other factors, even though the spread in study abroad participation rates by income group is not that large (see Table 2). (In the senior-survey-based data, income is family income; in the comprehensive data-based estimate it is family contribution.) Every additional $\$ 1,000$ in family contribution increases the likelihood of a student studying abroad by .2 percent. Thus a student who does not receive any aid at all would have about an 8 percent higher probability of study abroad than a student with a minimum family contribution.

We attribute the small size of the income effect to the effectiveness of MHC's financial support for study abroad. Despite the fact that many external provider programs cost less than studying at Mount Holyoke College (MHC), many of our students could not afford to study abroad without financial aid. MHC does not charge home school fees, and financial aid does not follow a student abroad automatically. Instead, students apply for Laurel fellowships, which substitute for the need-based aid that they would receive if they studied at MHC. In recent years, the college has typically funded 80 to 85 percent of the applications.

\section{Risk Aversion}

The probit analysis provides some support for the hypothesis that riskaverse students at Mount Holyoke College are less likely to study abroad. Although the coefficient on early decision is negative in the comprehensive data based estimate, it is not statistically significant. On the other hand, the results indicate that students who travel the farthest to attend Mount Holyoke are the most likely to study abroad. Compared to students from the New England states (the omitted variable), students from the Pacific region are 9.5 percent more likely to study abroad, and students whose home is abroad (nonU.S.) are 15 percent more likely to study abroad. 


\section{College-related variables}

The statistical results show that major and GPA are powerful factors influencing a Mount Holyoke student's likelihood to study abroad. Student athletes are not less likely to study abroad than non-athletes.

Mirroring the national study abroad profile by major, science majors at Mount Holyoke are much less likely to study abroad than language majors. In fact, science majors are 65.8 percent less likely to study abroad than language majors based on the senior survey estimate and 51.5 percent less likely in the comprehensive data. Concern about meeting major requirements may be one reason why science majors are less likely to study abroad. In the senior survey, we asked members of the class of 2007 to assess the relative importance of different factors in their decision not to study abroad. Students put the need to fulfill major requirements at the top of the list (see Table 3). Although a third of the non-study abroad students listed concern about participation in athletics as an obstacle to study abroad, the probit analysis shows that athletics does not seem to play an important role in keeping students from studying abroad.

Table 3. Relative Importance of Perceived Obstacles to Studying Abroad

\begin{tabular}{|l|l|}
\hline Need to fulfill major requirements & 57.0 \\
\hline Concern about financing & 47.2 \\
\hline Participate in athletics & 32.2 \\
\hline Concern about credits transferring & 28.6 \\
\hline Family obligations & 25.8 \\
\hline Apprehension about different environment & 15.5 \\
\hline Concerns about safety abroad & 11.5 \\
\hline
\end{tabular}

(\% of students that did not study abroad who considered the factor 'very important' or 'important', $\mathrm{n}=238$ )

We find that students with a higher GPA are much more likely to study abroad. Based on the responses of the 2007 senior survey, half of the students with a GPA in the A-range studied abroad, whereas the study abroad ratio of those with a GPA in the B-range was only slightly over 20 percent. The estimation results in Table 1 suggest that an increase in the GPA of one point (on a four point scale) leads to a 20 to 30 percent increase in a student's likelihood to study abroad.

It may be that students with a lower GPA feel less confident about their ability to succeed abroad. While we may not think of a B average as "low," many students attending highly selective colleges perceive any grade less than an $\mathrm{A}$ or $\mathrm{A}-$ as inadequate. Students may also feel pressure to raise their GPA, which cannot happen on the basis of work abroad at institutions that, like 
Mount Holyoke, transfer in only credit and not grades. Or students may have unrealistic ideas about the difficulty of gaining admission to a good program or university abroad, especially if they are focusing only on the most prestigious universities (e.g., Oxford) as worthwhile options.

\section{Encouragement factors}

Encouragement by faculty or parents is a key determinant of study abroad at Mount Holyoke College. The senior survey-based estimate shows large and significant effects of 32 and 22 percent, respectively. Some care must be taken in interpreting these results since the students are answering the encouragement question as seniors, after their study abroad experience. It is possible that some of those who did not study abroad may not want to reveal they received encouragement and then chose not to go and that some of those who did go abroad may have idealized memories of their encouragement. But it is highly unlikely that such behavior is the main reason for the significant coefficients on the encouragement variables.

Table 4. Effect of Encouragement on Decision to Study Abroad

\begin{tabular}{|l|c|c|c|}
\hline $\begin{array}{c}\text { Encouragement } \\
\text { from }\end{array}$ & $\begin{array}{c}\text { \% studying } \\
\text { abroad that } \\
\text { were strongly } \\
\text { encouraged }\end{array}$ & $\begin{array}{c}\text { \% studying } \\
\text { abroad that } \\
\text { were } \\
\text { encouraged }\end{array}$ & $\begin{array}{c}\text { \% studying } \\
\text { abroad that } \\
\text { were not } \\
\text { encouraged }\end{array}$ \\
\hline Parents & 77.9 & 63.5 & 27.2 \\
\hline Friends & 79.1 & 58.3 & 28.5 \\
\hline Faculty & 88.2 & 60.6 & 27.7 \\
\hline
\end{tabular}

Of the students who were strongly encouraged to study abroad, more than three quarters did indeed do so; but among the students who were not encouraged, only slightly more than one quarter studied abroad (see Table 4). The encouragement factor seems to be closely linked to the under-representation of science majors in study abroad. Students in the sciences report substantially less encouragement from faculty members than students in the other divisions (see Table 5).

Although we did not ask students specifically about the departmental origin of the faculty who encouraged them to study abroad, it is a reasonable supposition that the faculty most likely to have played an important role in a student's decision to study abroad were indeed the faculty in the student's major. Very few students in the sciences were actively discouraged from studying abroad, but the important point is that they did not feel encouraged either. 
Table 5. Students by Division Indicating the Importance of Faculty (Parent) Support in their Decision to Study Abroad (percentage distribution by division)

\begin{tabular}{|l|c|c|c|c|}
\hline & Sciences & $\begin{array}{l}\text { Social } \\
\text { Sciences }\end{array}$ & Humanities & Languages \\
\hline Strongly & 11.4 & 31.4 & 38.6 & 80.8 \\
encouraged & $(25.7)$ & $(31.6)$ & $(32.4)$ & $(51.9)$ \\
\hline Encouraged & 21.4 & 22.4 & 18.8 & 11.5 \\
& $(31.4)$ & $(24.1)$ & $(32.4)$ & $(33.3)$ \\
\hline Played no role & 57.1 & 38.5 & 35.6 & 7.7 \\
& $(41.4)$ & $(36.7)$ & $(30.4)$ & $(14.8)$ \\
\hline Discouraged & 8.6 & 6.4 & 5.9 & 0 \\
& $(10)$ & $(7)$ & $(4.9)$ & $(0)$ \\
\hline Strongly & 1.4 & 1.3 & 1.0 & 0 \\
Discouraged & $(1.4)$ & $(.6)$ & $(0)$ & $(0)$ \\
\hline
\end{tabular}

Table 6. Encouragement for Studying Abroad from Faculty, Parents, Friends: Probit Model Results

\begin{tabular}{|c|c|c|c|c|c|c|}
\hline & Coeff & Marg. Ef. & Coeff & Marg. Ef. & Coeff & Marg. Ef. \\
\hline Family Income & 0.13 & $5.0 \%$ & 0.23 & $9.1 \%$ & 0.14 & $5.4 \%$ \\
\hline First Generation & 0.11 & $4.4 \%$ & -0.49 & $-18.6 \%$ & -0.26 & $-10.2 \%$ \\
\hline Early Decision & 0.03 & $1.3 \%$ & 0.23 & $9.3 \%$ & -0.09 & $-3.4 \%$ \\
\hline Languages & 1.15 & $37.4 \%$ & 0.98 & $33.7 \%$ & 1.01 & $34.3 \%$ \\
\hline Science & -0.44 & $-17.1 \%$ & -0.28 & $-10.9 \%$ & -0.22 & $-8.8 \%$ \\
\hline Social Science & 0.06 & $2.2 \%$ & -0.15 & $-6.1 \%$ & 0.02 & $0.9 \%$ \\
\hline Humanities & -0.05 & $-2.2 \%$ & -0.13 & $-5.1 \%$ & -0.33 & $-12.8 \%$ \\
\hline College GPA & 0.43 & $16.5 \%$ & $\underline{0.38}$ & $14.7 \%$ & 0.16 & $6.2 \%$ \\
\hline Athlete & 0.08 & $3.3 \%$ & 0.14 & $5.7 \%$ & 0.22 & $8.5 \%$ \\
\hline Asian & 0.24 & $9.4 \%$ & -0.08 & $-3.4 \%$ & 0.09 & $3.6 \%$ \\
\hline $\begin{array}{l}\text { African-American } \\
\text { and } \\
\text { Hispanic }\end{array}$ & -0.22 & $-8.6 \%$ & $\underline{-0.61}$ & $-22.9 \%$ & -0.36 & $-13.9 \%$ \\
\hline International & 0.03 & $1.2 \%$ & 0.03 & $1.1 \%$ & -0.10 & $-4.2 \%$ \\
\hline Intercept & -2.46 & & -2.40 & & -1.24 & \\
\hline $\mathrm{N}$ & 329 & & 329 & & 329 & \\
\hline Log-Likelihood & -199.1 & & -200.5 & & -210.6 & \\
\hline
\end{tabular}

bold: significant at the $5 \%$ level, italic: significant at the $10 \%$ level.

Seventy percent of science majors who reported having been strongly encouraged by faculty did study abroad. But for the majority of science majors, faculty members did not play a role in their study abroad decision. 
Parent support seems to be particularly important when analyzing study abroad behavior across race. All the African-American students who responded to our senior survey indicated that they had not received parental encouragement to study abroad, and none of them studied abroad. However, since the number of African-American students who answered the survey is small, these results can only be taken as suggestive.

To explore encouragement for studying abroad further we estimated three additional models, with parent, faculty and friends encouragement variables as the dependent variables. The results of these models are shown in Table 6. In the 'faculty model,' language majors and students with a higher GPA were more likely to receive encouragement from faculty and parents to study abroad. Parents are more likely to encourage their daughter's study abroad plans if they have higher income and if they attended college. It is also interesting that African-American/Hispanic students are 23 percent less likely to receive parental support than Caucasian students.

\section{Conclusions: Faculty is the Key}

In this paper we presented a general model of the determinants of study abroad which included student background characteristics, student comfort with risk and cultural difference, college-related factors, and encouragement effects. We estimated a probit model of study abroad for Mount Holyoke College students. The results indicate that among student background variables, racial background was not a statistically significant determinant, whereas family income was of some importance. Among our proxies for risk-aversion, early decision was not significant, but the geographical distance of a student's home from Mount Holyoke College was significant. Regarding college-related variables, both major and GPA were significant; and for the encouragement factors, parent and faculty encouragement were statistically significant determinants of an MHC student's decision to study abroad.

Paus (2007) provides a detailed discussion of the policy conclusions Mount Holyoke College has drawn from this analysis. Our discussion in this section focuses mainly on how faculty members might play a more active role in encouraging students to study abroad. Enlisting more parents in encouraging their children to seek out learning abroad opportunities is a much greater challenge. This is partly because colleges and universities have much less direct contact with parents, and partly because of the tension between the recognition of the key role parents can play and the institutional philosophy and privacy laws that limit the nature of institutional relationships with them. Outreach 
to parents must avoid setting a false expectation that the college will share information with the parent about the student's academic record or even about her conversations with the study abroad staff.

Colleges and universities need to make the case for learning abroad to parents who are skeptical, or perhaps ill-informed about what kinds of programs are available and whether they are financially feasible. As a first step in that direction, Mount Holyoke College sent all parents a copy of a student brochure "Invest in Your Future, Learn Abroad." The hope is that the brochure will spark interest in parents who might not have thought about learning abroad opportunities for their daughter, or open a window for discussion with those who have already dismissed it as impractical or not worthwhile. The relevant decision-makers in higher education will need to think a lot harder about how best to reach parents who are not convinced of the importance of learning abroad for their children, and to develop strategies to address their doubts and concerns, while maintaining appropriate boundaries around student confidentiality and rights to privacy.

The role of faculty encouragement in a student's study abroad decision has mostly been neglected in the literature; but increased involvement of the faculty may well hold the key to tackling barriers to student participation in study abroad, not only in particular majors, but also with respect to risk aversion and GPA. Faculty and parent encouragement for study abroad may well be decisive if we aim for a quantum leap in study abroad participation.

Our finding about the importance of faculty encouragement speaks from a different angle — to the same issue raised by Stohl (2007), who argued that faculty engagement was key to the internationalization of higher education in the 21 st century. "If we want to internationalize the university, we have to internationalize the faculty. We have to move them in the necessary directions. We thus need to consider not only how to do what needs to be done but also how what needs to be done affects the faculty and how we can mobilize their power over the process." (367)

In conversations with faculty members at Mount Holyoke we found that most are quite supportive of study abroad. But support in the abstract does not necessarily translate into support in practice. Professors may not discuss learning abroad with their students for a variety of reasons. In certain majors, like foreign languages, the importance of learning abroad to the major is selfevident. In other majors, it is less obvious; and a professor may not necessarily have thought about the importance of learning abroad. In addition, faculty members may not be well-informed about study abroad opportunities. Some 
faculty may consider a discussion about learning abroad outside of their purview or responsibility.

The McCulloch Center for Global Initiatives at Mount Holyoke, which incorporates the study abroad office, decided to move information about learning abroad and procedures beyond the general efforts of that office to the academic department and program level. With the goal of developing study abroad web pages tailor-made to each department and program, the McCulloch Center staff decided to visit with departments to discuss the educational benefits of learning abroad, study abroad and summer opportunities for each particular major, and how faculty members in the department might leverage their international research collaborations to secure a summer internship for students.

As a pilot, the Center for Global Initiatives worked with the chemistry department to develop a 'Learning Abroad for Chemistry Majors' webpage. The page emphasizes the importance of learning abroad, whether it relates directly to the major or fits more generally with a student's overall academic program; provides recommendations on study abroad programs; guidelines for sequencing coursework to accommodate time away from campus; as well as recommendations on summer internships and research abroad that our recent students have found substantive and meaningful. It links to a searchable database which includes all the courses that students took abroad and received credit for at MHC since 2001.

Faculty members and learning abroad staff can become true partners in the expansion and enhancement of learning abroad by developing resources together. The final outcome of this process will be faculty members who are more engaged with learning abroad, and students who will feel more encouraged, as departmental web pages and their advisors send clear messages about the value and possibilities of learning abroad.

There are other important ways through which faculty members can become more involved in integrating learning abroad into their students' education. York University, for example, held a conference on learning abroad for scientists, with other scientists as the featured panelist. A number of universities send faculty members abroad to assess the fit for students of specific programs and universities with the curriculum at home. Another, more indirect, strategy for enlisting faculty as advocates of learning abroad, is to facilitate short-term faculty visits abroad where the focus is on research and intellectual exchange and not exclusively on program and department assessment. Such visits, which are often linked to university partnerships, are intellectually exciting to faculty members and can have serendipitous outcomes for faculty's perspectives on 
learning abroad. International partnerships hold out great promise for faculty development in many respects. A 'world faculty' (McGill Patterson 2000) is a critical component of any effort to internationalize students' education.

Some universities and colleges have developed specific programs in which learning abroad constitutes an integral part. Examples include the Global Citizenship Program at Lehigh University and the International Bachelor of Science in Biology, Conservation Ecology, and Computer Science at York University. ${ }^{3}$ And at some colleges, departments have changed their course sequencing to make study abroad more compatible with major requirements on the home campus. Kalamazoo College, for example, requires each academic department to design its requirements and course sequences in a way that assumes that majors will study abroad for all or part of their junior year.

When faculty are convinced of the value of learning abroad and see how it would fit into their students' course of study and the kind of opportunities that are available, they are much more likely to encourage their students to pursue such possibilities. They will be more likely to make learning abroad an integral part of conversations with advisees from day one. Students from under-represented groups or students who are more risk averse may well be more likely to consider learning abroad as a viable and important option.

\section{Notes}

${ }^{1}$ At a per class level, the participation rate was 4.7 percent, ranging from 10 percent at doctoral institutions to 0.3 percent at associate colleges. The calculations are based on IIE (2007) and Carnegie Foundation (2005). According to Daly and Barker (2005), study abroad rates in Australia and New Zealand are similar to the ones in the U.S., with less than one percent participating in 2000-2001.

${ }^{2}$ http://international.yorku.ca/global/conference/science/scienceprog.pdf

${ }^{3}$ See http://www.lehigh.edu/ ingc/gcindex.htm and http://www.science. yorku.ca/futurestudents/programs/iBSc/index.html 


\section{Refere nces}

Carnegie Foundation. 2005. 2005 Carnegie Classification; National Center for Educations Statistics, IPEDS Fall Enrollment (2004). http://www.carnegiefoundation.org/classifications/index.asp?key=805

Commission on the Abraham Lincoln Study Abroad Fellowship Program. 2005. "Global Competence \& National Needs. One Million Americans Studying Abroad."http://www.nafsa.org/_Document/_lincoln_commission_report.pdf

CBO (Congressional Budget Office). 2007. "Cost Estimate. H.R. 1469. Senator Paul Simon Study Abroad Foundation Act of 2007. http://www.cbo. gov/ftpdocs/79xx/doc7999/hr1469.pdf

Chieffo, Lisa P. 2000. Determinants of Student Participation in Study Abroad Programs at the University of Delaware: A Quantitative Study. Doctoral Dissertation.

Daly, Amanda J. \& Barker, M.C. 2005. “'Australian and New Zealand University students' participation in international exchange programs," Journal of Studies in International Education, 9, 26-41.

Dessoff, Alan. 2007. “Who's NOT Going Abroad?” International Educator March-April, 20-27.

Forum on Education Abroad. 2005. "A Baseline Survey of Curriculum Integration in Education Abroad," http://www.forumea.org/documents/surveyfinal.pdf

Goldstein, Susan B. and Randi I. Kim. 2006. "Predictors of US College Students' Participation in Study Abroad Programs: A Longitudinal Study," International Journal of Intercultural Relations 30, 507-521.

Hulstrand, Janet. 2007. What Parents Need to Know! Before, during, and after Education Abroad. NAFSA

Institute for International Education. 2007. Open Doors: Report on International Educational Exchange. New York, NY: IIE.

Jackson, Marilyn J. 2005. “Study Abroad for Students of Color,” IIE Networker. Fall, 16-18.

LeMay Burr, Pat. 2005. "Building Study Abroad Acceptance among Hispanic Students," IIE Networker. Fall, 36-38.

McGill Patterson, Patti. 2000. "The Worthy Goal of a Worldly Faculty,” Peer Review 3, reprinted at http://www.cies.org/Reprint_8pp.pdf

NAFSA. 2006. Americans call for Leadership on International Education," http://www.nafsa.org/_Document/_/americans_call_for_leadership.pdf Pappano, Laura. 2007. “A semester in Ghana: \$4,725. A year in Beijing: \$ 35,150. Experience Abroad: Priceless?" New York Times. Education Life. Nov 4, 30-36. 
Frontiers: The Interdisciplinary Journal of Study Abroad

Paus, Eva. 2007. "Global Education for All Students: Innovation \& Integration in Expanding Learning Abroad," A Teagle Foundation White Paper (with Jale Okay and Joanne Picard),http://www.teaglefoundation.org/learning/ pdf/mtholyoke_whitepaper.pdf.

Stohl, Michael. 2007. "We Have Met the Enemy and He is Us: The Role of the Faculty in the Internationalization of Higher Education in the Coming Decade," Journal of Studies in International Education 11, 3-4, 359-372.

Thompson, Hannah. 2007. "Engage your Campus with the World. Best Practices 2007," IIE Networker, Spring, 16-23.

Van Der Meid, J. Scott. 2003. "Asian Americans: Factors Influencing the Decision to Study Abroad," Frontiers. The Interdisciplinary Journal of Study Abroad. IX, Fall, 71-110. 